University of Nebraska - Lincoln

DigitalCommons@University of Nebraska - Lincoln

Distribution of Structural Carbohydrates in Corn Plants Across the Southeastern USA

\author{
Spyridon Mourtzinis \\ szm0020@tigermail.auburn.edu \\ Keri B. Cantrell \\ USDA-ARS, kbcantre@ncsu.edu \\ Francisco J. Arriaga \\ USDA-ARS, Francisco.arriaga@ars.usda.gov \\ Kipling S. Balkcom \\ USDA-ARS, kip.balkcom@ars.usda.gov \\ Jeff M. Novak \\ USDA-ARS, jeff.novak@ars.usda.gov \\ See next page for additional authors
}

Follow this and additional works at: https://digitalcommons.unl.edu/usdaarsfacpub

Mourtzinis, Spyridon; Cantrell, Keri B.; Arriaga, Francisco J.; Balkcom, Kipling S.; Novak, Jeff M.; Frederick, James R.; and Karlen, Douglas, "Distribution of Structural Carbohydrates in Corn Plants Across the Southeastern USA" (2014). Publications from USDA-ARS / UNL Faculty. 1643.

https://digitalcommons.unl.edu/usdaarsfacpub/1643

This Article is brought to you for free and open access by the U.S. Department of Agriculture: Agricultural Research Service, Lincoln, Nebraska at DigitalCommons@University of Nebraska - Lincoln. It has been accepted for inclusion in Publications from USDA-ARS / UNL Faculty by an authorized administrator of DigitalCommons@University of Nebraska - Lincoln. 


\section{Authors}

Spyridon Mourtzinis, Keri B. Cantrell, Francisco J. Arriaga, Kipling S. Balkcom, Jeff M. Novak, James R. Frederick, and Douglas Karlen 


\title{
Distribution of Structural Carbohydrates in Corn Plants Across the Southeastern USA
}

\author{
Spyridon Mourtzinis • Keri B. Cantrell • Francisco J. Arriaga • \\ Kipling S. Balkcom • Jeff M. Novak • James R. Frederick • \\ Douglas L. Karlen
}

Published online: 9 February 2014

(C) Springer Science+Business Media New York 2014

This document is a U.S. government work and is not subject to copyright in the United States.

\begin{abstract}
Quantifying lignin and carbohydrate composition of corn (Zea mays L.) is important to support the emerging cellulosic biofuels industry. Therefore, field studies with 0 or $100 \%$ stover removal were established in Alabama and South Carolina as part of the Sun Grant Regional Partnership Corn Stover Project. In Alabama, cereal rye (Secale cereale L.) was also included as an additional experimental factor, serving as a winter cover crop. Plots were located on major soil types representative of their respective states: Compass and Decatur soils in Alabama and a Coxville/Rains-Goldsboro-Lynchburg soil association in South Carolina. Lignin and structural carbohydrate concentrations in the whole (above-ground) plant, cobs, vegetation excluding cobs above the primary ear (top), vegetation below the primary ear (bottom), and vegetation from above the primary ear including cobs (above-ear fraction) were determined using near-infrared spectroscopy
\end{abstract}

S. Mourtzinis $(\triangle)$

Auburn, AL, USA

e-mail: szm0020@tigermail.auburn.edu

K. B. Cantrell $\cdot$ J. M. Novak

USDA-ARS, Coastal Plains Soil, Water, and Plant Research Center,

Florence, SC 29501, USA

F. J. Arriaga

Department of Soil Science, University of Wisconsin,

Madison, WI 53706, USA

K. S. Balkcom

National Soil Dynamics Research Laboratory, USDA-Agricultural

Research Service, Auburn, AL 36832, USA

J. R. Frederick

Pee Dee Research and Education Center, Clemson University,

Florence, SC 29501, USA

D. L. Karlen

USDA-ARS, National Laboratory for Agriculture and the

Environment, Ames, IA 50011, USA
(NIRS). The distribution of lignin, ash, and structural carbohydrates varied among plant fractions, but neither inclusion of a rye cover crop nor the stover harvest treatments consistently affected carbohydrate concentrations within locations. Total precipitation and average air temperature during the growing season were strongly correlated with stover composition indicating that weather conditions may have multiple effects on potential biofuel production (i.e., not only yield but also stover quality). When compared to the above-ear fractions, bottom plant partitions contained greater lignin concentrations. Holocellulose concentration was consistently greater in the above-ear fractions at all three locations. Data from this study suggests that the above-ear plant portions have the most desirable characteristics for cellulosic ethanol production via fermentation in the southeastern USA.

Keywords Corn · Carbohydrates · Lignin · Cellulose · Distribution $\cdot$ Rye $\cdot$ Residue removal

\section{Introduction}

Global demand for renewable bioenergy feedstock has increased substantially during the past millennium. Corn stover has been identified as a major second-generation nonfood agricultural feedstock for bioenergy purposes [1] because, while most abundant in Midwestern state, it is grown across the USA. Corn stover is a readily available and inexpensive feedstock for biofuel production through enzymatic ethanol or thermochemical conversion processing [2]. Therefore, improving biomass yield and/or the conversion efficiency could provide substantial economic benefit to interested industries [3].

The biofuel yield of any conversion process can be significantly affected by biomass composition [4]. The main components of the plant tissue are cellulose, hemicellulose, lignin, and ash [5]. Cellulose and hemicellulose are structural 
polysaccharides of plant cell walls [6] with the former being a polymer of glucose and, as a major plant component, the most abundant carbohydrate on earth [7]. Cellulose is therefore the most desirable plant component for cellulosic ethanol production through fermentation, with lignin being identified as the least desirable component, which is known to inhibit biomass hydrolysis $[8,9]$. Nevertheless, for thermochemical biofuel production, lignin-rich biomass would be desirable due to its high energy content [10].

Literature related to whole-plant corn stover composition as well as that within various plant parts dates back to the late 1920s. According to an old study [11], the composition of corn stalks (percentage of dry weight) is $28.7 \%$ cellulose, $21.9 \%$ hemicellulose, $9.5 \%$ lignin, and $7.5 \%$ ash. In a more recent study [12], lignin accounted for $18.7 \%$ of the corn stover, while through decades of crop improvement and hybridization, carbohydrates accounted for $58.3 \%$ of total biomass. Several studies have indicated the heterogeneity of corn biomass composition and the impact on cellulose enzymatic hydrolysis [13-15]. A 2009 study [15] suggested that stover from above the ear had a higher quality for fermentation and that the lower portion (below the ear) was wetter and likely to have soil contamination (i.e., increased ash content). This vertical heterogeneity may also be influenced by genetic differences [2] and yearly environmental variations [16].

A major concern associated with harvesting crop residues as bioenergy feedstock is potential negative impact of biomass removal on overall soil quality and long-term productivity due to a decrease in $C$ inputs to soil [17-19]. Incorporating cover crops in a crop rotation is a prospective management strategy to offset potential negative consequences from residue harvest [20]. In the southeastern USA, cereal rye (Secale cereale L.) has been identified as a winter cover crop with large biomass production potential [21]. Minimizing soil quality impacts may also be achieved through alternative management strategies, such as only harvesting certain portions of the corn stover. For instance, to balance soil residue needs with downstream fermentation needs, it has been proposed to collect only the fraction of corn stover with the greatest glucose content [22]. The stover left in the field would thus be available for soil erosion control and to help sustain soil organic matter. Therefore, it would be valuable for soil management purposes to identify portions of the stover with desirable composition for biofuel production.

As previously stated, $\mathrm{C}$ inputs to soil in the form of crop residue additions impact soil chemical, physical, and microbiological properties, as well as crop productivity. Although there is information in the literature on how drought stress [23], planting densities [24], and crop development stage [25] affect biomass composition, data regarding how altering $\mathrm{C}$ inputs through crop residue returns to the soil (e.g., $\mathrm{C}$ inputs due the use of cover crops and reduced $\mathrm{C}$ inputs due to stover harvest) and its impact on stover composition are lacking. Our objective was to assess impacts of southeastern US corn management practices on stover carbohydrate composition averaged over multiple years (3) through three separate studies designed to determine

1. if average temperature and cumulative rainfall during the growing season and stover composition were correlated;

2. if altering $\mathrm{C}$ inputs to the soil by using cereal rye as a winter cover crop and harvesting corn residue affected composition of corn; and

3. the vertical distributions of lignin, ash, and structural carbohydrates in corn stover harvested at three locations across the southeastern USA.

\section{Materials and Methods}

\section{Site Description}

This study was conducted from 2009-2011 at two locations in Alabama (AL) and one location in South Carolina (SC). The first location in AL was the EV Smith Research Center (EVS) in central Alabama $(32.43 \mathrm{~N},-85.89 \mathrm{~W})$ with a mean annual precipitation (MAP) of $1,330 \mathrm{~mm}$ and mean annual temperature (MAT) of $18^{\circ} \mathrm{C}$. The second AL location was the Tennessee Valley Research and Extension Center (TVS) in Belle Mina $(34.69 \mathrm{~N},-86.89 \mathrm{~W})$ in the northern part of the state with MAP of $1,380 \mathrm{~mm}$ and MAT of $16^{\circ} \mathrm{C}$. The soil at EVS was a Compass loamy sand (coarse-loamy, siliceous, subactive, thermic Plinthic Paleudults), while at TVS, the soil was a Decatur silt loam (fine, kaolinitic, thermic Rhodic Paleudults). The SC study was at the Clemson University Pee Dee Research and Education Center (PDREC) in Florence $(34.28 \mathrm{~N},-79.74 \mathrm{~W})$, with a MAP of $1,300 \mathrm{~mm}$ and MAT of $17^{\circ} \mathrm{C}$. There were several soil series mapped in the plots at the PDREC site, but they comprise of a typical Coxville/RainsGoldsboro-Lynchburg soil association.

Treatments in the SC site were arranged in a randomized complete block design with four replications. Individual plot size was $137.6 \mathrm{~m}^{2}$. Treatments included two levels of corn residue management ( 0 and $100 \%$ removal rates). Both sites in $\mathrm{AL}$ were arranged in a split-plot design with three replications with plots $16.7 \mathrm{~m}^{2}$ in size. Main plots consisted of cereal rye as a winter cover with three levels (no cover, rye as a cover crop harvested in spring, and rye retained after chemical termination with glyphosate), and subplots were two corn residue removal levels ( 0 and $100 \%$ removal). A single $\mathrm{N}$ fertilizer rate of $168 \mathrm{~kg} \mathrm{ha}^{-1}$ was applied to all plots in SC and in AL. In late winter of every year in $\mathrm{AL}, 34 \mathrm{~kg} \mathrm{ha}^{-1} \mathrm{~N}$ was applied to all plots with cereal rye as a winter cover. DeKalb C69-71 corn hybrid was grown in SC, while Pioneer 31G65R was grown at both locations in AL. Urea ammonium nitrate (UAN 28-0-0) was 
used as the nitrogen source in all three sites, while $\mathrm{P}$ and $\mathrm{K}$ were applied based on soil test results. The plots in SC were under nonirrigated continuous corn production, which included annual strip-till to a depth of 30 to $40 \mathrm{~cm}$. Corn in AL was grown continuously in a no-till system without irrigation.

\section{Weather Data and Sample Collection}

Daily precipitation and air temperature data were collected from weather stations located at each experimental site. $\mathrm{Cu}-$ mulative precipitation (in millimeters) and average air temperature (in degrees Celsius) at $1.5 \mathrm{~m}$ above ground during the entire growing seasons (from sowing to harvest) were calculated and used as independent variables.

The corn plants in SC were harvested at physiological maturity, while plants in Alabama were harvested at grain harvest between mid-September to mid-October depending on the year and location. Two 1-m row lengths from the center rows of the plots were sampled at each location. Corn grain and cobs were separated from the stalks. The grain was separated from the cobs using a shelling machine. Stalks were further separated into four increments: below the ear (bottom), above the ear excluding cobs (top), and the cobs alone. An additional fraction of the total stover included in the analysis was the above-the-ear portion, which included top and cobs (above-ear fraction). The compositional characteristics of the above-ear portion were calculated using a dry biomass yield weighted average of the top and cob fractions. Stover samples were oven-dried for approximately 7 days at 55 to $60{ }^{\circ} \mathrm{C}$ until constant weight and ground in a Wiley mill to pass through a 2-mm sieve.

\section{NIR Preprocessing}

Near-infrared spectroscopy (NIRS) techniques were employed for sample analysis. To ensure appropriate calibration of the NIR that would capture a wide range of compositional characteristics, all ground samples from all three locations ( $\sim 400)$, along with 2,100 corn tissue samples from other experiments, were scanned and analyzed with a FOSS 5000 NIRS instrumentation using the ISIscan ${ }^{\mathrm{TM}}$ and WinISI 4 software (C) FOSS Analytical AB 2004). After scanning all the samples, the Standard Normal Variate (SNV) and Detrend (Detrend) scatter correction in WinISI4 were used to reduce particle size effects and remove the linear and quadratic curvatures from the spectra. The spectra were then ranked according to the global Mahalanobis distance $(\mathrm{GH})$, and then, representative samples from the entire GH range were chosen for wet chemistry analysis.

Chemical Analysis

Chemical analysis of a selected subset of samples was conducted to calibrate the NIR system to the specific corn material from this study. Wet chemistry procedures [26, 27] were used to determine neutral detergent fiber (NDF), acid detergent fiber (ADF), acid detergent lignin (ADL), and ash content, for the selected corn tissue samples. Cellulose content was calculated by the difference of ADF-ADL. Hemicellulose content was calculated by the difference of NDF-ADF. Lignin content was calculated by the difference of ADL-ash. Holocellulose was defined as the summation of cellulose and hemicellulose. Although the applied wet chemistry methods tend to overestimate cellulose and hemicellulose and underestimate lignin [28], the data obtained were considered valid for the purposes of this study.

\section{NIR Calibration}

The most appropriate regression method for the calibration of the NIRS data was the modified partial least squares (modified PLS). The math treatment used for the calibration was the (1, $4,4,1)$. This math treatment involved the first derivative, a 4$\mathrm{nm}$ gap with four initial smoothing points, and no further smoothing. The standard error of calibration (SEC) and the standard error of cross validation (SECV) were the lowest achieved concurrently with the highest possible $R^{2}$ values (Table 1). To further evaluate the accuracy of the developed models, an additional dataset $(n=160)$ of plant tissue with known carbohydrate content values was included and scanned in the NIRS with the stover samples. The actual compositional values in these samples were compared to the NIRS-derived values. There was no significant difference between the actual and NIRS-predicted values, which was an additional indication of the acceptable performance of the NIRS models.

\section{Statistical Analysis}

This multilocation study was not designed nor intended to examine corn stover composition differences among locations, soil types, or between hybrids. The CORR procedure in SAS 9.3 (SAS for Windows v. 9.3, SAS Institute Inc., Cary, $\mathrm{NC}$ ) was used to detect correlations among weather conditions during the growing season and individual components across total and partitions of corn biomass pooling treatments within

Table 1 Statistics for the near-infrared spectroscopy (NIRS) calibration using compositional chemical analysis of a selected subset of samples from the entire dataset

\begin{tabular}{llll}
\hline Compositional attributes & SEC & $R^{2}$ & SECV \\
\hline Cellulose & 1.086 & 0.9103 & 1.528 \\
Hemicellulose & 1.68 & 0.9090 & 1.812 \\
Lignin & 0.591 & 0.8653 & 0.678 \\
Ash & 0.362 & 0.8818 & 0.505 \\
\hline
\end{tabular}

$S E C$ standard error of calibration, $S E C V$ standard error of cross validation 
locations. Repeated measures analysis of variance, utilizing the GLIMMIX procedure and the AR (1) covariance structure, was used to detect differences in the partial biomass composition due to the 3-year average effect of rye cultivation and of corn residue management at every location. Four plant portions were of interest: the bottom portion (bottom); top portion excluding cobs (top); cobs alone (cob); and the plant portion above the first ear (above-ear fraction), which was calculated as a weighted average of the top portion of the plant and the cobs. Since the above-ear fraction was not mutually exclusive from the tops and cobs, its compositional characteristics were compared only against the bottom portion of the stover within locations. A factor was considered to be significant at a level lower than $0.05(\alpha=0.05)$.

\section{Results and Discussion}

\section{In-Season Weather Effects on Biomass Composition}

In nonirrigated agriculture, one of the most limiting factors in corn production is the lack of adequate water. Cumulative precipitation levels and average air temperatures varied over the nine location-years of this experiment (Table 2). However, at all three sites, significant moderate to strong correlations were detected between the season weather conditions and stover compositional characteristics (Table 3). More specifically, at the SC site, significant correlations were detected between the weather variables (seasonal cumulative precipitation and average air temperature) and cellulose components in all plant parts (Table 3). Similarly, holocellulose content exhibited strong correlations similar in direction to cellulose. Ash content in biomass was negatively correlated with seasonal precipitation and positively with air temperature. At both AL sites, the correlations were not as strong as in SC and varied between

Table 2 Seasonal cumulative precipitation and seasonal average temperature during the three growing seasons (May-August) at the Pee Dee Research and Education Center in South Carolina (SC), the EV Smith Research Center (EVS) in central Alabama, and the Tennessee Valley Research and Extension Center (TVS) in northern Alabama

\begin{tabular}{llll}
\hline Location & Year & $\begin{array}{l}\text { Cumulative } \\
\text { precipitation }(\mathrm{mm})\end{array}$ & $\begin{array}{l}\text { Average } \\
\text { temperature }\left({ }^{\circ} \mathrm{C}\right)\end{array}$ \\
\hline SC & 2009 & 648 & 24.0 \\
& 2010 & 693 & 25.9 \\
& 2011 & 293 & 26.0 \\
EVS & 2009 & 976 & 24.3 \\
& 2010 & 514 & 25.8 \\
& 2011 & 427 & 26.4 \\
TVS & 2009 & 808 & 22.6 \\
& 2010 & 367 & 24.8 \\
& 2011 & 329 & 25.5 \\
\hline
\end{tabular}

positive and negative. Cellulose, lignin, and holocellulose contents in total stover and partitions were positively correlated with cumulative seasonal precipitation and negatively correlated with seasonal average air temperatures (Table 3 ).

It appears that there was a biomass compositional response to climate variations. As precipitation increased during each growing season, the lignin content decreased in the DeKalb hybrid (SC location). Conversely, as precipitation increased in $\mathrm{AL}$, lignin content increased in the Pioneer hybrid. These variations could be attributed to genetic differences between corn hybrids [2] and/or differences in environmental conditions [16]. These results suggest that the differences in biomass composition can affect the amount of biofuel produced due to seasonal and regional climate variations. Therefore, it is important to conduct in-depth research on the specific effects of climate impacts on biomass composition and quantify the cellulosic ethanol potential of corn plants grown in different climate regions.

Rye and Corn Stover Management Effect on Biomass Composition

Harvesting corn stover or including rye cover crop had minimal impact on chemical composition at any of the sites (data not shown). Even in the few cases that were identified as significant, the mean compositional change due to management practices were $<1 \%$ for cellulose content and $<0.5 \%$ for ash content; therefore, they are of low practical importance. The lack of compositional variation due to residue management implies that $100 \%$ corn stover removal would not have an impact on the downstream bioenergy production practices using stover as a feedstock. However, the duration of the experiment should be considered before recommending longterm corn stover harvesting practices. A long-term study could reveal significant variations in the chemistry of corn stover tissue as a result of residue management practices and impacts to soil properties. Additionally, despite the limited effect of rye on stover composition, the benefits on soil productivity of cover crops under conservation tillage practices should always be considered [29, 30]. Furthermore, retention of rye in the field could reduce soil contamination on feedstock and cause microclimate interaction that affect water retention properties and soil heating properties in the spring. These interactions could affect biomass yield and compositional characteristics beyond the levels observed in this study.

\section{Vertical Biomass Composition}

Total and partial biomass composition was highly variable at all three locations (Table 4). These variations, in addition to the compositional responses to in-season climate, further indicate the possible differences between the two experimental corn varieties. However, there were similarities in the way that the components of interest were distributed among different plant 
Table 3 Pearson correlations ( $r$ values) between total precipitation and average temperature during the growing season (May-August) with major plant components in total stover and partitions of corn stover biomass at the
Pee Dee Research and Education Center in South Carolina (SC), the EV Smith Research Center (EVS) in central Alabama, and the Tennessee Valley Research and Extension Center (TVS) in northern Alabama

\begin{tabular}{|c|c|c|c|c|c|}
\hline & Above-ear & Bottom & Top & Cob & Stover \\
\hline Location & $\mathrm{SC}$ & & & & \\
\hline \multicolumn{6}{|l|}{ Cellulose (\%) } \\
\hline Total precipitation & $0.504 * *$ & $0.454^{* *}$ & $0.505^{* *}$ & $0.386^{*}$ & $0.621 * * *$ \\
\hline Average temperature & $-0.714^{* * *}$ & $-0.647 * * *$ & $-0.732 * * *$ & $-0.576^{* * *}$ & $-0.759 * * *$ \\
\hline \multicolumn{6}{|l|}{ Hemicellulose (\%) } \\
\hline Total precipitation & $0.788 * * *$ & $0.907 * * *$ & $0.911 * * *$ & 0.279 & $0.704 * * *$ \\
\hline Average temperature & -0.304 & $-0.355^{*}$ & $0.458^{* *}$ & -0.043 & -0.089 \\
\hline \multicolumn{6}{|l|}{ Holocellulose (\%) } \\
\hline Total precipitation & $0.861 * * *$ & $0.897 * * *$ & $0.866^{* * *}$ & $0.719 * * *$ & $0.916^{* * *}$ \\
\hline Average temperature & $-0.688^{* * *}$ & $-0.564^{* * *}$ & $-0.643^{* * *}$ & $-0.640 * * *$ & $-0.585 * * *$ \\
\hline \multicolumn{6}{|l|}{ Lignin $(\%)$} \\
\hline Total precipitation & $-0.635^{* * *}$ & $-0.871^{* * *}$ & $-0.877 * * *$ & 0.242 & $-0.710^{* * *}$ \\
\hline Average temperature & -0.186 & 0.235 & 0.250 & $-0.841 * * *$ & -0.144 \\
\hline \multicolumn{6}{|l|}{ Ash $(\%)$} \\
\hline Total precipitation & $-0.747^{* * *}$ & $-0.725^{* * *}$ & $-0.619^{* * *}$ & $-0.787 * * *$ & $-0.819 * * *$ \\
\hline Average temperature & $0.625 * * *$ & $0.360 *$ & $0.587 * * *$ & $0.569 * *$ & $0.678 * * *$ \\
\hline Location & EVS & & & & \\
\hline \multicolumn{6}{|l|}{ Cellulose (\%) } \\
\hline Total precipitation & $0.409 * * *$ & $0.311^{* *}$ & 0.075 & $0.546^{* * *}$ & $0.393 * * *$ \\
\hline Average temperature & $-0.488^{* * *}$ & $-0.428 * * *$ & -0.189 & $-0.568 * * *$ & $-0.494 * * *$ \\
\hline \multicolumn{6}{|l|}{ Hemicellulose (\%) } \\
\hline Total precipitation & $-0.246^{*}$ & $-0.375^{* * *}$ & -0.217 & $-0.234^{*}$ & $-0.321 * *$ \\
\hline Average temperature & $0.243^{*}$ & $0.412 * * *$ & 0.221 & 0.202 & $0.342 * *$ \\
\hline \multicolumn{6}{|l|}{ Holocellulose (\%) } \\
\hline Total precipitation & $0.278^{* *}$ & 0.103 & -0.076 & $0.478 * * *$ & $0.240^{*}$ \\
\hline Average temperature & $-0.362 * * *$ & -0.206 & -0.021 & $-0.519 * * *$ & $-0.338 * *$ \\
\hline \multicolumn{6}{|l|}{ Lignin (\%) } \\
\hline Total precipitation & $0.736^{* * *}$ & $0.546^{* * *}$ & $0.579 * * *$ & $0.672 * * *$ & $0.709 * * *$ \\
\hline Average temperature & $-0.723 * * *$ & $-0.636^{* * *}$ & $-0.585^{* * *}$ & $-0.636^{* * *}$ & $-0.755 * * *$ \\
\hline \multicolumn{6}{|l|}{ Ash $(\%)$} \\
\hline Total precipitation & $-0.626^{* * *}$ & $0.581 * * *$ & $-0.292 * *$ & $-0.525^{* * *}$ & 0.214 \\
\hline Average temperature & $0.581 * * *$ & $-0.534^{* * *}$ & $0.334 * *$ & $0.450 * * *$ & -0.203 \\
\hline Location & TVS & & & & \\
\hline \multicolumn{6}{|l|}{ Cellulose (\%) } \\
\hline Total precipitation & $0.291 * *$ & 0.001 & 0.159 & $0.542 * * *$ & 0.217 \\
\hline Average temperature & $-0.339 * *$ & -0.152 & -0.222 & $-0.498 * * *$ & $-0.318^{* *}$ \\
\hline \multicolumn{6}{|l|}{ Hemicellulose (\%) } \\
\hline Total precipitation & $-0.441 * * *$ & $0.540 * * *$ & -0.135 & $-0.452 * * *$ & -0.023 \\
\hline Average temperature & $0.477 * * *$ & $-0.429 * * *$ & $0.262 *$ & $0.356 * * *$ & 0.120 \\
\hline \multicolumn{6}{|l|}{ Holocellulose (\%) } \\
\hline Total precipitation & -0.046 & $0.651^{* * *}$ & 0.071 & $-0.245^{*}$ & $0.265^{*}$ \\
\hline Average temperature & 0.025 & $-0.701 * * *$ & -0.004 & 0.149 & $-0.309 * *$ \\
\hline \multicolumn{6}{|l|}{ Lignin (\%) } \\
\hline Total precipitation & $0.743 * * *$ & $0.505^{* * *}$ & $0.717 * * *$ & $0.306^{* *}$ & $0.777 * * *$ \\
\hline Average temperature & $-0.698 * * *$ & $-0.599 * * *$ & $-0.749 * * *$ & -0.169 & $-0.788 * * *$ \\
\hline \multicolumn{6}{|l|}{ Ash (\%) } \\
\hline Total precipitation & $-0.297 * *$ & 0.066 & $-0.356^{* * *}$ & 0.043 & -0.174 \\
\hline Average temperature & 0.212 & -0.217 & $0.311^{* *}$ & -0.142 & 0.041 \\
\hline
\end{tabular}

$* 0.1, * * 0.05$, and $* * * 0.01$ probability levels 
Table 4 Descriptive statistics [mean (standard error)] in total stover and partitions of major plant components as quantified by near-infrared spectroscopy (NIRS) from corn tissue samples collected at the Pee Dee Research and Education Center in South Carolina (SC), the EV Smith Research Center (EVS) in central Alabama, and the Tennessee Valley Research and Extension Center (TVS) in northern Alabama

\begin{tabular}{lcrrrr}
\hline Plant fraction & Stover $(\%)$ & Bottom (\%) & Top $(\%)$ & Cob (\%) & Above-ear (\%) \\
\hline Location & \multicolumn{1}{l}{ SC } & & & & \\
$\quad$ Cellulose & $41.13(0.98)$ & $43.36(0.91)$ & $37.1(0.77)$ & $39.21(1.10)$ & $37.73(0.80)$ \\
Hemicellulose & $31.97(0.99)$ & $25.98(1.53)$ & $36.43(1.25)$ & $40.69(0.87)$ & $37.7(0.86)$ \\
Lignin & $5.97(0.48)$ & $9.04(1.04)$ & $5.28(0.53)$ & $4.36(0.30)$ & $5(0.33)$ \\
Holocellulose & $73.1(1.42)$ & $69.31(2.01)$ & $73.62(1.76)$ & $79.78(0.93)$ & $75.46(1.25)$ \\
Ash & $3.97(0.14)$ & $4.12(0.16)$ & $3.45(0.21)$ & $2.07(0.16)$ & $3.03(0.19)$ \\
Location & EVS & & & & \\
Cellulose & $41.76(0.18)$ & $42.2(0.25)$ & $39.46(0.18)$ & $38.49(0.18)$ & $39.13(0.17)$ \\
Hemicellulose & $21.98(0.14)$ & $17.27(0.21)$ & $24.23(0.17)$ & $30.29(0.14)$ & $26.22(0.12)$ \\
Lignin & $6.49(0.06)$ & $8.13(0.10)$ & $5.34(0.07)$ & $5.15(0.05)$ & $5.27(0.05)$ \\
Holocellulose & $63.74(0.17)$ & $59.46(0.25)$ & $63.7(0.22)$ & $68.78(0.20)$ & $65.37(0.16)$ \\
Ash & $2.87(0.02)$ & $4.09(0.05)$ & $4.16(0.03)$ & $2.32(0.03)$ & $3.55(0.03)$ \\
Location & TVS & & & & \\
Cellulose & $41.22(0.18)$ & $42.20(0.24)$ & $39.46(0.16)$ & $38.49(0.18)$ & $39.19(0.18)$ \\
Hemicellulose & $22.72(0.16)$ & $17.27(0.26)$ & $24.23(0.20)$ & $30.29(0.19)$ & $25.86(0.14)$ \\
Lignin & $6.56(0.08)$ & $8.13(0.11)$ & $5.34(0.10)$ & $5.16(0.06)$ & $5.29(0.07)$ \\
Holocellulose & $63.94(0.15)$ & $59.46(0.25)$ & $63.7(0.16)$ & $68.78(0.18)$ & $65.07(0.15)$ \\
Ash & $3.43(0.04)$ & $4.09(0.07)$ & $4.17(0.03)$ & $2.32(0.03)$ & $3.67(0.03)$ \\
\hline
\end{tabular}

Table 5 Comparison of major plant components among the bottom, top, and cob fractions as quantified by near-infrared spectroscopy (NIRS) from corn tissue samples collected at the Pee Dee Research and Education Center in South Carolina (SC), the EV Smith Research Center (EVS) in central Alabama, and the Tennessee Valley Research and Extension Center (TVS) in northern Alabama

\begin{tabular}{lccrr}
\hline Plant fraction & Bottom (\%) & Top (\%) & Cob (\%) & $\operatorname{Pr}>F^{\mathrm{a}}$ \\
\hline Location & SC & & & \\
Cellulose & $43.36 \mathrm{a}$ & $37.10 \mathrm{~b}$ & $39.21 \mathrm{c}$ & $<0.0001$ \\
Hemicellulose & $25.98 \mathrm{a}$ & $36.43 \mathrm{~b}$ & $40.69 \mathrm{c}$ & $<0.0001$ \\
Lignin & $9.04 \mathrm{a}$ & $5.28 \mathrm{~b}, \mathrm{c}$ & $4.36 \mathrm{c}$ & 0.0003 \\
Holocellulose & $69.31 \mathrm{a}$ & $73.62 \mathrm{~b}$ & $79.78 \mathrm{c}$ & $<0.0001$ \\
Ash & $4.12 \mathrm{a}$ & $3.45 \mathrm{~b}$ & $2.07 \mathrm{c}$ & $<0.0001$ \\
Location & EVS & & & \\
Cellulose & $42.20 \mathrm{a}$ & $39.46 \mathrm{~b}$ & $38.49 \mathrm{c}$ & $<0.0001$ \\
Hemicellulose & $17.27 \mathrm{a}$ & $24.23 \mathrm{~b}$ & $30.29 \mathrm{c}$ & $<0.0001$ \\
Lignin & $8.13 \mathrm{a}$ & $5.34 \mathrm{~b}$ & $5.15 \mathrm{~b}$ & $<0.0001$ \\
Holocellulose & $59.46 \mathrm{a}$ & $63.70 \mathrm{~b}$ & $68.78 \mathrm{c}$ & $<0.0001$ \\
Ash & $4.09 \mathrm{a}$ & $4.16 \mathrm{a}$ & $2.32 \mathrm{~b}$ & $<0.0001$ \\
Location & TVS & & & \\
Cellulose & $42.20 \mathrm{a}$ & $39.46 \mathrm{~b}$ & $38.49 \mathrm{c}$ & $<0.0001$ \\
Hemicellulose & $17.27 \mathrm{a}$ & $24.23 \mathrm{~b}$ & $30.29 \mathrm{c}$ & $<0.0001$ \\
Lignin & $8.13 \mathrm{a}$ & $5.34 \mathrm{~b}$ & $5.16 \mathrm{~b}$ & $<0.0001$ \\
Holocellulose & $59.46 \mathrm{a}$ & $63.70 \mathrm{~b}$ & $68.78 \mathrm{c}$ & $<0.0001$ \\
Ash & $4.09 \mathrm{a}$ & $4.17 \mathrm{a}$ & $2.32 \mathrm{~b}$ & $<0.0001$ \\
\hline
\end{tabular}

Means within row followed by the same letter are not significantly different at the 0.05 level. Separation of means was achieved using the Tukey adjustment for multiple comparisons

${ }^{\text {a }} \operatorname{Pr}>F$ values represent the probability of a larger $F$ by chance between plant fractions within locations
Table 6 Comparison of major plant components between the bottom and above-ear fractions as quantified by near-infrared spectroscopy (NIRS) from corn tissue samples collected at the Pee Dee Research and Education Center in South Carolina (SC), the EV Smith Research Center (EVS) in central Alabama, and the Tennessee Valley Research and Extension Center (TVS) in northern Alabama

\begin{tabular}{lccc}
\hline Plant fraction & Bottom (\%) & Above-ear (\%) & $\operatorname{Pr}>F^{\mathrm{a}}$ \\
\hline Location & SC & & \\
Cellulose & 43.36 & 37.73 & $<0.0001$ \\
Hemicellulose & 25.98 & 37.70 & $<0.0001$ \\
Lignin & 9.04 & 5.00 & 0.0033 \\
Holocellulose & 69.31 & 75.46 & $<0.0001$ \\
Ash & 4.12 & 3.03 & $<0.0001$ \\
Location & EVS & & \\
Cellulose & 42.20 & 39.13 & $<0.0001$ \\
Hemicellulose & 17.27 & 26.22 & $<0.0001$ \\
Lignin & 8.13 & 5.27 & $<0.0001$ \\
Holocellulose & 59.46 & 65.37 & $<0.0001$ \\
Ash & 4.09 & 3.55 & $<0.0001$ \\
Location & TVS & & $<0.0001$ \\
Cellulose & 42.20 & 39.19 & $<0.0001$ \\
Hemicellulose & 17.27 & 25.86 & $<0.0001$ \\
Lignin & 8.13 & 5.29 & $<0.0001$ \\
Holocellulose & 59.46 & 65.07 & $<0.0001$ \\
Ash & 4.09 & 3.67 & \\
\end{tabular}

${ }^{\mathrm{a}} \mathrm{The} \operatorname{Pr}>F$ values represent the probability of a larger $F$ by chance between plant fractions within locations 
portions across locations. Among the three stover fractions (Table 5), the greatest holocellulose content was observed in the above-ear fractions and cobs; alternatively, the least amount of holocellulose was detected in the bottom plant fractions; and lastly, the bottom portions of the stover exhibited the greatest amount of lignin, while the upper fractions of the stover contained the lowest amounts. These results are in agreement with a study conducted near Ames in IA [31]. The only component distributed differently among the plant parts between state locations was the ash content. At SC, the least amount of ash was detected in the cobs and the greatest amount of ash was measured in the bottom stover portion, while at both sites in $\mathrm{AL}$, the ash content was not significantly different between bottom and top fractions. When comparing the bottom and above-ear fractions (Table 6), the bottom portion exhibited significantly greater cellulose, lignin, and ash content at all three locations. The above-ear fractions had greater hemicellulose and holocellulose content and lower lignin than the bottom portion. The observed distribution of lignin and structural carbohydrates indicates that the above-ear fraction has more desirable composition for cellulosic ethanol conversion than the bottom plant portion. These results are in agreement with previous studies which also identified the stover fraction above the first ear as a higher-quality fermentation feedstock $[15,31,32]$.

It is known that corn stover biomass can be used by the bioenergy industry for biofuel production [33]. Biomass feedstock with large amounts of cellulose and hemicellulose and low lignin is the most desirable for cellulosic production via fermentation $[8,9]$. During the 3 years of the experiment across all three locations, the cobs, tops, and above-ear portions exhibited the greatest holocellulose contents and lowest amounts of ash and lignin. Therefore, regardless of corn hybrid used here, climate, or soil type associated with corn production, the top, cob, and above-ear fractions seemed to have the most suitable compositional characteristics for cellulosic ethanol production via fermentation.

\section{Conclusions}

Cellulosic corn stover biomass can be used as feedstock for biofuel production. In this multilocation study, the 3-year average effect of both corn residue removal ( 0 and $100 \%$ removal) and of rye cultivation was minimal on biomass composition. There were numerical differences between corn hybrid in the quantitative vertical distribution of structural carbohydrates, lignin, and ash content. However, at all three sites, the relative distribution of cellulose, hemicellulose, and lignin was similar among different plant portions. Due to the strong correlations between biomass composition and in-season weather conditions, it is necessary to further investigate climate impacts on downstream biofuel production. Results from this study indicate that the above-ear fractions of both corn hybrids grown in major soil types of the southeastern USA have the more desirable composition for cellulosic ethanol production via fermentation relative to the below-ear portion.

Acknowledgments The authors would like to thank the many hands aiding in the corn planting, harvest collections, sample preparations, and analyses. Mention of a trade name, proprietary product, or vendors is for information only and does not guarantee or warrant the product by the USDA and does not imply its approval to the exclusion of other products or vendors that may also be suitable. The USDA is an equal opportunity employer.

Funding Partial funding for this research was provided by the Alabama Wheat and Feed Grain Producers Commission of the Alabama Farmers Federation. This study is a contribution of the multilocation USDA-ARSREAP, supported in part by supplemental funding from the North Central Regional Sun Grant Center at South Dakota State University through a grant provided by the USDOE-Office of Biomass Programs under award number DE-FC36-05GO85041.

\section{References}

1. Wilhelm WW, Johnson JMF, Lightle DT, Karlen DL, Novak JM, Barbour NW, Laird DA, Baker J, Ochsner TE, Halvorson AD, Archer DW, Arriaga F (2010) Vertical distribution of corn stover dry mass grown at several US locations. Bioenerg Resour 4:11-21

2. Thomas S, Ruth M, Macfarlane B, Hames BE (2001) Estimating the effects of compositional variation on biomass conversion process economics. Biofuels Program FY01 C Milestone report \#FY01273, NREL

3. Lorenz A, Coors J, de Leon N, Wolfrum E, Hames B, Sluiter A, Weimer P (2009) Characterization, genetic variation, and combining ability of maize traits relevant to the production of cellulosic ethanol. Crop Sci 49:85-98

4. Philip Y, Lu L, Hayes D, Womac A, Hong K, Sokhansanj S (2008) Fast classification and compositional analysis of corn stover fractions using Fourier transform near-infrared techniques. Bioresour Technol 99:7323-7332

5. Cone JW, Van Gelder AH, Marvin HJP (1996) Influence of drying method and ageing on chemical and physical properties and in vitro degradation characteristics of grass and maize samples. J Agr Sci 126:7-14

6. Hatfield RD (1989) Structural polysaccharides in forages and their degradability. Agron J 46:39-46

7. Chandrakant P, Bisaria VS (1998) Simultaneous conversion of cellulose and hemicellulose to ethanol. Crit Rev Biotechnol 18:295-331

8. Chang VS, Holtzapple MT (2000) Fundamental factors affecting biomass enzymatic reactivity. Appl Biochem Biotechnol $84: 5-38$

9. Kim S, Holtzapple MT (2006) Effect of structural features on enzyme digestibility of corn stover. Bioresour Technol 97:583-591

10. Klass DL (1998) Biomass for renewable energy, fuels, and chemicals. Academic, London

11. Waksman T (1928) The composition of natural organic materials. Soil Sci Soc Am 26:155-171

12. Kim S, Dale BE (2004) Global potential bioethanol production from waste crops and crop residues. Biomass Bioenergy 26:361-375

13. Akin DE, Morrison WH, Rigsby LL, Barton FE, Himmelsbach DS, Hicks KB (2006) Corn stover fractions and bioenergy: chemical composition, structure, and response to enzyme pretreatment. Appl Biochem Biotechnol 129-132:104-116 
14. Bootsma JA, Shanks BH (2005) Hydrolysis characteristics of tissue fractions resulting from mechanical separation of corn stover. Appl Biochem Biotechnol 125:27-39

15. Duguid KB, Montross MD, Radtke CW, Crofcheck CL, Wendt LM, Shearer SA (2009) Effect of anatomical fractionation on the enzymatic hydrolysis of acid and alkaline pretreated corn stover. Bioresour Technol 100:5189-5195

16. Templeton D, Sluiter AD, Hayward TK, Hames B, Thomas T (2009) Assessing corn stover composition and sources of variability via NIRS. Cellulose 16:621-639

17. Johnson JMF, Novak JM, Varvel GE, Stott DE, Osborne SL, Karlen DL, Lamb JA, Baker J, Adler, PR (2014) Crop residue mass needed to maintain soil organic carbon levels: can it be determined? Bioenergy Res 10. 10.1007/s12155-013-9402-8

18. Lehman M, Ducey TF, Jin VL, Acosta-Martinez V, Ahlschwede, CM, Jeske, ES, Drijber, RA, Cantrell, KB, Frederick JR, Fink DM, Osborne SL, Novak JM, Johnson, JMF, Varvel, GE (2014) Soil microbial community response to corn stover harvesting under rainfed, no-till conditions at multiple U.S. locations. Bioenergy Research this issue

19. Osborne SL, Johnson JMF, Jin VL, Hammerbeck, AL, Varvel GE, Schumacher TE (2014) The impact of corn residue removal on soil aggregates and particulate organic matter. Bioenergy Research this issue

20. Wilhelm WW, Hess JR, Karlen DL, Johnson JMF, Muth DJ, Baker JM, Gollany HT, Novak JM, Scott DE, Varvel GE (2010) Review: Balancing limiting factors and economic drivers for sustainable Midwestern US agricultural residue feedstock supplies. Ind Biotechnol 6:271-287

21. Moschler WW, Shear GM, Hallock DL, Sears RD, Jones GD (1967) Winter cover crops for sod-planted corn: their selection and management. Agron J 59:547-551

22. Crofcheck CL, Montross MD (2004) Effect of stover fraction on glucose production using enzymatic hydrolysis. Trans Am Soc Agric Eng 47:841-844
23. Schittenhelm S (2010) Effect of drought stress on yield and quality of maize/sunflower and maize/sorghum intercrops for biogas production. J Agron Crop Sci 196:253-261

24. Hansey CN, de Leon N (2011) Biomass yield and cell wall composition of corn with alternative morphologies planted at variable densities. Crop Sci 51:1005-1015

25. Pordesimo LO, Hames BR, Sokhansanj S, Edens WC (2005) Variation in corn stover composition and energy content with crop maturity. Biomass Bioenergy 28:366-374

26. Van Soest PJ (1963) Use of detergents in the analysis of fibrous feeds. II. A rapid method for the determination of fiber and lignin. J Assoc Off Anal Chem 46:828

27. Van Soest PJ, Wine RH (1967) Use of detergents in the analysis of fibrous feeds. IV. Determinations of plant cell wall constituents. J Off AssocAnal Chem 50:50

28. Wolfrum EJ, Lorenz AJ, deLeon N (2009) Correlating detergent fiber analysis and dietary fiber analysis data for corn stover collected by NIRS. Cellulose 16:577-585

29. Bruce RR, Langdale GW, West LT, Miller WP (1995) Surface soil degradation and soil productivity restoration and maintenance. Soil Sci Soc Am J 59:654-660

30. Sainju UM, Singh BP, Whitehead WF (2002) Long-term effects of tillage, cover crops, and nitrogen fertilization on organic carbon and nitrogen concentrations in sandy loam soils in Georgia, USA. Soil Tillage Res 63:167-179

31. Hoskinson RL, Karlen DL, Birrell SJ, Radtke CW, Wilhelm WW (2007) Engineering, nutrient removal, and feedstock conversion evaluations of four corn stover harvest scenarios. Biomass Bioenergy 31:126-136

32. Johnson JMF, Wilhelm WW, Karlen DL, Archer DW, Wienhold B, Lightle DT, Laird D, Baker J, Ochsner TE, Novak JM, Halvorson AD, Arriaga F, Barbour N (2010) Nutrient removal as a function of corn stover cutting height and cob harvest. Bioenergy Res 3:342-352

33. Kadam K, McMillan J (2003) Availability of corn stover as a sustainable feedstock for bioethanol production. Bioresour Technol 88:17-25 